\title{
References:
}

1. Arkushyn, Gh. L. (2016). Slovotvir zoonimiv pivnichno-zakhidnoji Ukrajiny [Word formation zoonims Northwestern Ukraine]. The typology and functions of linguistic units, no. 2, pp. 5-16. (in Ukrainian)

2. Barannyk, D. Kh. (1969). Prykmetnyk [Adjective]. Suchasna ukrajinsjka literaturna mova. Morfologhija [Modern Ukrainian literary language. Morphology]. Kyjiv: Scientific thought. (in Ukrainian)

3. Dubova, N. Gh. (1980). Dejaki osoblyvosti klychok myslyvsjkykh sobak [Some features of hunting dog nicknames]. Onomastics question, vol. 14, pp. 145-149. (in Ukrainian)

4. Ghorpynych, V. O. (2004). Morfologhija ukrajinsjkoji movy [Morphology of the Ukrainian language]. Kyjiv : Academy. (inUkrainian)

5. Kovtjukh, S. L. (2002). Morfologhichna paradyghmatyka substantyvovanykh chastyn movy [Morphological paradigm of substantiated parts of language]. Scientific notes, vol. 44, pp. 5-10. (in Ukrainian)

6. Kovtjukh, S. L., \& Kyryljuk, O.L. (2010). Kinonimija v suchasnij ukrajinsjkij movi: pryncypy nominaciji ta sposoby tvorennja [Kinonymy in modern Ukrainian: nomination principles and ways of creation]. Kirovoghrad: DLAU. (in Ukrainian)

7. Poljarush, T. I. (2009). Mikrotoponimija i miscevyj lingvaljnyj kontekst [Microtoponymy and local lingual context]. Studia Slovakistica, vol. 10, pp. 372-384. (in Ukrainian)

8. Sjusjko, M. I. (2014). Pytannja suchasnoji ukrajinsjkoji literaturnoji ta zhyvorozmovnoji movy [Problems of modern Ukrainian language and folk language]. Uzhghorod : Ghrazhda. (in Ukrainian)

9. Torchynsjkyj, M. M. (2008). Struktura onimnogho prostoru ukrajinsjkoji movy [Structure of proper names of the Ukrainian language]. Khmeljnycjkyj : Avist. (in Ukrainian)

10. Vykhovanecj, I. R. (1993). Ghramatyka ukrajinsjkoji movy. Syntaksys [Grammar of the Ukrainian language. Syntax]. Kyiv : Lybidj. (in Ukrainian)

11. Vykhovanecj, I. R., \& Ghorodensjka, K. Gh. (2004). Teoretychna morfologhija ukrajinsjkoji movy [Theoretical morphology of the Ukrainian language]. Kyiv : Pulsars. (in Ukrainian)

\section{THE IMPORTANCE OF ONOMASTIC ANALYSIS IN THE STUDY OF LITERARY WORKS}

\section{Anna Shotova-Nikolenko ${ }^{1}$}

DOI: https://doi.org/10.30525/978-9934-588-11-2_48

In the system of general theory of artistic speech, which is characterized by versatility, a variety of creative approaches to the literary texts and idiostyles of their authors, from the second half of the twentieth century was actively developed one of its important branches - the theory of literary onomastics, which was initiated by significant works of the scientists Yu. O. Karpenko, V. M. Mikhailov, O. V. Superanskaya, etc. The onomastic researches will always have scientific relevance, novelty and perspective, since the studying of proper names is inexhaustible in the illimitable ocean of the world literature.

\footnotetext{
${ }^{1}$ Odesa State Environmental University, Ukraine
} 
Proper names and literary work are the links of one lexical system created by its auther to realize his conception. Therefore, the studying of the onym space of a specific literary work, the analysis of onym functions which are striking, powerful features of the author's penmanship, are very important to understand the unique linguistic view of an author's creative imagination.

In his work «About the Language of Fiction» (1959), V. V. Vinogradov emphasized: "The language of the playwriter, the language of the lyricist, the language of the novelist - are different in their semantic structure, stylistic tasks, in their constructive principles. These differences are largely dependent on the specific properties of different genres of verbal-artistic creativity and different types of artistic language» [1, p. 21].

In the article «Some Problems of Literary Onomastics» (1988), T. V. Nemirovskaya proposed a scheme of division of literary onymia by genres of a literary work: 1) onymia of poetry, or poetic onomastics, - lyrics, poems, ballads; 2 ) onymia of prose, or artistic onomastics, - stories, novels; 3) onymia of dramaturgy, or dramatic onomastics, - comedies, dramas, tragedies [3, p. 112-113].

With regard to the typology of poetic onymia, Yu. O. Karpenko in his work «The typology of poetic onymia: M. Bazhan, B. Pasternak, P. Tychyna» (1992) emphasizes the lyrical principle (the figurativeness of proper names, their phonetic instrumentation), the epic principle (the significance of proper names, their direct, not figurative use), the humorous principle (the combination of not combining, the focusing on laugh), as well as the lyrical (changeable and colorful like a rainbow) or epic (powerful and monumental like a tower) principles of choice and use of proper names [2, p. 19].

O. I. Fonyakova considers poetic creativity as one that represents the maximum freedom of search, the principles of the name usage and the ways of its transformation: the freedom of associative approximation and comparison, the creation of a new form and meaning in context, the searching for new ways of incorporation into the context, the creation of semantic versatility and diffuseness of artistic semantics of proper name. In the poetic text, onym always undergoes a certain transformation, depending on the author's purpose, capable of focusing the reader's attention like no other means of lexical nomination, because the range of his connotations is unusually wide $[4, \mathrm{p} .81]$.

The dynamic nature of the semantics of the onyms, their ability to accumulate all forms of information refers to the named objects, made them extremely attractive, especially in poetry, a means of figurativeness [4, p. 222], creating brief metaphorical contexts [4, p. 77]. The great importance of proper names in the creation of artistic time-space, inherent in one form or another to all literary works, is well known. In poetry, it is especially growing: both laconic and more precise [2, p. 19].

The onomastic investigations include the method of description and its main techniques: observation, interpretation, generalization; a basic functional and stylistic method for studying literary onomastics is applied, which involves a broad involvement of contextual analysis. The use of the statistical method helps to 
generalize the data obtained during in the systematic analysis, and to confirm reliability thereof.

The main purpose of the onomastic research on literary onomastics is to analyze the onymic content of a literary work, that is, the functional loading of proper names, their participation in the creation of an artistic whole, the peculiarities of usage of onyms in literary works.

The studying in the field of literary onomastics involves the following tasks:

1) identification and systematization of proper names of all onomastic classes used in writer's works;

2) establishing the frequency and variability of each proper name in the works;

3) identification of onymic changes and variations recorded in different editions of the studied works;

4) interpretation of the functional loading of proper names and consideration of each onym in particular;

5) defining the specific features of proper names in the context of works, their expressive and stylistic role, the relationship between the genre of the work and proper names;

6) comparison of features of onyms' usage in the novels of a writer or a poet.

So literary onomastics investigates the role and problems, mechanisms, stages of studying proper names in the work, analyzes the role of proper names in creating a unique artistic world of the literary work and in revealing the creative idea of the author. Among the unresolved problems in literary onomastics is the definition of the boundaries of onomastic vocabulary in the literary work, since they have been very blurred in the individual-author's speech. There are also differences in the description of onyms' semantics and functions. Thus, the study of the functioning of onomastic vocabulary in the language of fiction (novels, verses, stories) is a voluminous and complex subject. It is stated that without the analysis of proper names, these central knots of artistic work, a real understanding of the text, its deep, subtext content layers is simply impossible. As it is known, the poetonymosphere (system of proper names) of an artistic work is the only solid cemented by the author's component of a work, which in the finished work of changes does not undergo. Each one is in its place, harmonizes with other onyms, working together for an artistic whole. But from the work to the work, depending on the literary direction, the depicted events, philosophical and outlook guides of the writer the poetonymosphere is definitely changing. There are no two identical works of one writer which would have the same system of proper names. Each work has its own system of proper names, which is unique and peculiar, as the literary work itself. The more skillful a writer, the more brightly he inserts onyms into his artistic canvas.

\section{References:}

1. Vinogradov, V. V. (1959). O yazyke khudozhestvennoy literatury [About the language of fiction]. Moscow: Goslitiz-dat. (in Russian)

2. Karpenko, Yu. O. (1992). Typolohiia poetychnoi onimii: M. Bazhan, B. Pasternak, P. Tychyna [Typology of Poetic Onymy: M. Bazhan, B. Pasternak, P. Tychyna]. Proceedings of the 
Shliakhy posylennia efektyvnosti praktychnoho kursu ukrainskoi movy ta vykhovannia chytatskoi maisternosti: Materialy obl. mizhvuz. nauk.-metod. konf. Odesa. (in Ukrainian)

3. Nemirovskaya, T. V. (1988). Nekotorye problemy literaturnoy onomastiki [Some problems of literary onomastics]. Aktual'nye voprosy russkoy onomastiki: Sbornik nauchnykh trudov [Actual issues of Russian onomastics: Collection of scientific papers]. Kiev: UMK VO. (in Russian)

4. Fonyakova, O. I. (1990). Imya sobstvennoe v khudozhestvennom tekste [Proper name in fiction]. Leningrad. (in Russian) 